\title{
A Review of Finite Element Analysis (FEA) of Resistance Spot Welding (RSW)
}

\section{Metoda analizy elementów skończonych (FEA) w zastosowaniu do zgrzewania rezystancyjnego punktowego (RSW)}

\begin{abstract}
Modeling RSW was studied by many researchers with considering different electrical, thermal, and mechanical phenomena such as formation of temperature field and welding nugget growth. This paper is a review of the most important efforts in the field of FEA of RSW, by investigating present finite element method (FEM) studies. After a brief introduction on FEA studies on RSW, such numerical solution methods as FEM and FDM (Finite Difference Method) are compared. Governing electrical, thermal, and mechanical equations are then discussed. A brief investigation about applicable algorithms is presented as a procedure for numerical solution. The importance of credible material properties is emphasized and predicted results in different studies are discussed. The final two parts are about recent issues in RSW FEA process and review of special cases such as multiple-sheet, single-sided welding, shunting effect, and covered models. Conclusions and suggestions about future studies are also provided.
\end{abstract}

Keywords: resistance spot welding, finite element analysis, review

\section{Streszczenie}

Modelowanie RSW było stosowane przez wielu badaczy z uwzględnieniem różnych zjawisk elektrycznych, cieplnych i mechanicznych, takich jak powstające pole temperatury czy wzrost jądra zgrzeiny. Niniejszy artykuł stanowi przegląd najważniejszych dokonań w obszarze zastosowania FEA w RSW, zwłaszcza wyników badań metodą elementów skończonych (FEM). Po krótkim wprowadzeniu do tematu przedstawiono porównanie takich metod obliczeń numerycznych jak FEM i FDM (metoda różnic skończonych) oraz dyskusję podstawowych równań elektrycznych, cieplnych i mechanicznych. Prześledzono i przedstawiono w skrócie algorytmy stosowane w procedurach rozwiązań numerycznych. Podkreślono znaczenie używania wiarygodnych danych materiałowych oraz przedyskutowano wyniki uzyskane w trakcie różnych studiów. Końcowe dwa akapity omawiają aktualne problemy FEA dla RSW, a także przegląd modeli dla szczególnych przypadków takich jak jednoczesne zgrzewanie kilku blach, zgrzewanie jednostronne, bocznikowanie prądu zgrzewania i zgrzewanie z nakładkami. Przedstawiono także podsumowanie i sugestie dla dalszych prac.

Słowa kluczowe: punktowe zgrzewanie rezystancyjne, analiza elementów skończonych, przegląd zagadnienia

\section{Introduction}

The early simulation works were generally on RSW steels. As the use of aluminum alloy sheets has increased rapidly in recent years in the automotive body assembly, research on RSW aluminum, including numerical simulation, has attracted more attention. The basic physical principles remain the same for resistance spot welding steels and aluminum alloys, so do the fundamental equations for simulation. However, there are major differences in the physical processes between welding aluminum alloys and steels, mainly due to their differences in mechanical, thermal, electrical, and metallurgical properties. For instance, because of its lower electrical resistance, aluminum requires higher welding currents, which can be about four times more than welding steel. Some parameters/properties, such as contact resistance, may not carry much weight in (uncoated) steel welding but are important in aluminum welding. Such differences make aluminum welding quite different from steel welding and warrant different treatment in numerical simulations.

Before 1980s most of analysis utilized one dimensional models which can't be reliable to obtain high precision results.

Mehdi Jafari Vardanjani - Department of Welding engineering, Warsaw University of Technology, Poland, on Sabbatical leave from department of Mechanical Engineering, University of Tehran, Iran; Jacek Senkara - Department of Welding engineering, Warsaw University of Technology, Poland, Alireza Arayee - Department of Mechanical Engineering, University of Tehran, Iran. 
Archer [1] in 1960 investigated the temperature variations caused by electrical current using a one dimensional model. After 1980s researchers tried to take the advantage of axisymmetric models in their finite element analysis. Greenwood [2] performed a research similar to Archer's study by the use of an axisymmetric model. Yamamoto and Okuda [14] also tried to predict the contact radius and calculate the temperature distribution by the use of similar model. A more advanced model was produced by Gould [3]. He investigated the growth of nugget experimentally and analytically for 1008 steel, and included the effects of melting, temperature dependence, electrode geometry, and heat transfer.

In 1980s researchers included electrical contact resistance in simulations. For example Nied [4] used a contact model between two sheets and analyzed the thermal deformations of stainless steels. Elastic equations were used in this study and the precision of the results was not very satisfactory.

Electrical, thermal, and mechanical fields are mostly included in the studies in a separate manner, and with a focus on thermal-electrical aspect. One of the most important researches focusing on thermal-electrical part is the 3D finite element modeling was performed by Huh and Kang [5] to simulate thermal and electrical field. The task was just to consider the durability of electrodes using an electrical-thermal coupled model while no mechanical analysis was included. The thermal-electrical model can be useful for determining some aspects of RSW process, but is not be broad enough for the future research. Loulou et al. [6] used the temperature history for different points to predict the electrical and thermal contact properties. Although Tsai [7] used ANSYS software to predict electrode voltage and displacement, the simulation was mostly based on thermal-electrical aspect. He showed the feasibility of a real-time control methodology by the use of FEA.

In the present paper, different methods of numerical solution, algorithms, theoretical equations, implementation of the dependence of material properties on temperature into models, and recent issues in RSW FEA are described. At the end some of the important FEA case studies of RSW process are considered.

\section{Methods}

\section{Different methods of numerical solution}

Both the FDM and FEM have been used in resistance spot welding process simulation. The FDM was used almost exclusively in early works, while the FEM took over in the recent efforts of simulating the RSW process. These two methods are different in terms of discretization, handling of boundaries, problem formulation, and simulation accuracy [8].

In FDA the object or region being analyzed is divided into a finite number of lumps while in FEA it consists of a finite number of elements. Thus, in a finite difference approach, each lump is assumed to have a constant value of a pertinent field variable. In the case of FEA the nodes are associated with the corners of an element and may have different values of field variables, like temperature, displacement, pressure, etc.

Discretizing complex geometries like curvatures on surfaces into lumps in FDM requires the use of jagged effective boundaries, while in FEM curved boundaries can be closely simulated using various types of elements, such as triangular (for plane problems) or tetrahedral (for three-dimensional problems) elements.

In FDM the governing equations are written for each node while in FEM the direct energy balance approach can be used, but there are some other approaches, like a virtual work, variational method, and weighted residual method, which are more powerful and flexible in engineering applications.

FEM seems to be more accurate when curved boundaries are present. It is also difficult to compare the execution times between FEM and FDM. In general, FEM needs longer execution times. On the other hand, FDM usually requires more preparation than FEM [8].

\section{Mathematical equations}

General mathematical equations used for electrical, thermal, and mechanical aspects of FEA of RSW process are provided below.

\section{Electrical equations}

The voltage distribution in the given weldment is considered together with the adjacent weld to investigate shunting effect. This voltage distribution is used to calculate shunt current alternations and heat generation while welding occurs. By using these assumptions the quasi-Laplace equation of electrical potential can be written in 3D coordinates as [9]:

$$
\frac{\partial}{\partial x}\left[\frac{1}{\rho} \cdot \frac{\partial \phi}{\partial x}\right]+\frac{\partial}{\partial y}\left[\frac{1}{\rho} \cdot \frac{\partial \phi}{\partial y}\right]+\frac{\partial}{\partial z}\left[\frac{1}{\rho} \cdot \frac{\partial \phi}{\partial z}\right]=0
$$

where $p$ is the bulk electrical resistivity.

\section{Thermal equations}

A thermal equation in continuous form for the temperature distribution inside the weldments is presented as [10]:

$$
\text { D.c. } \frac{\partial T}{\partial t}=\frac{\partial}{\partial x}\left[k \cdot \frac{\partial T}{\partial x}\right]+\frac{\partial}{\partial y}\left[k \cdot \frac{\partial T}{\partial y}\right]+\frac{\partial}{\partial z}\left[k \cdot \frac{\partial T}{\partial z}\right]+\frac{1}{\rho} \nabla \phi . \nabla \phi
$$

where $D$ is volumetric mass density, $c$ is specific heat capacity, $k$ is thermal conductivity coefficient, $T$ is temperature, and $\Phi$ is electrical potential.

\section{Mechanical equations}

The main equation used for mechanical analysis to make relation between stress, strain, andthermal expansion is the incremental elastic-plastic equation [15]:

$$
d\{\sigma\}=\lceil C\rceil d\{\epsilon\}-\left\{C_{T}\right\} d T
$$

Where $d\{\sigma\}$ is stress vector differences, [C] is elastic-plastic matrix, $d\{\}$ is strain vector differences, $\left\{C_{T}\right\}$ is thermal coefficient vector, and $d T$ : temperature differences.

For stress equilibrium, following equations is used:

$$
\nabla\{\sigma\}_{x y z}+D .\{b\}=D .\{a\}
$$

where $\{b\}$ is body force vector, which is not considered in this analysis, $\{a\}$ is acceleration vector, which is a very small parameter and is usually considered to be zero [15].

All of the equations introduced in this section are generally used for FEA of RSW and they might change to some extent depending on the chosen coordinates system and number of dimensions, however the main concept and basic form are the same.

\section{Electrical-thermal-mechanical contact detection}

The common method of detecting the contact between two weldments or weldment and electrode is uses a spring-like 
layer at the contact area. The main purpose of this layer is to detect the mechanical contact. It is detected by checking the value of different but interrelated parameters. Vertical reaction force, strain, and stress of the contacting layer are usually considered to check the mechanical contact in every element of the layer. If the value of the parameter is negative, the mechanical contact should be assumed, otherwise there is no contact. Presence of mechanical contact means electrical and thermal contact should also be established between the two entities. There for electrical and thermal conductive parameters are set according to contact status. This approach can be seen in figure 1 as an algorithm. Figure 2 indicates the model containing contact layers between each pairs.

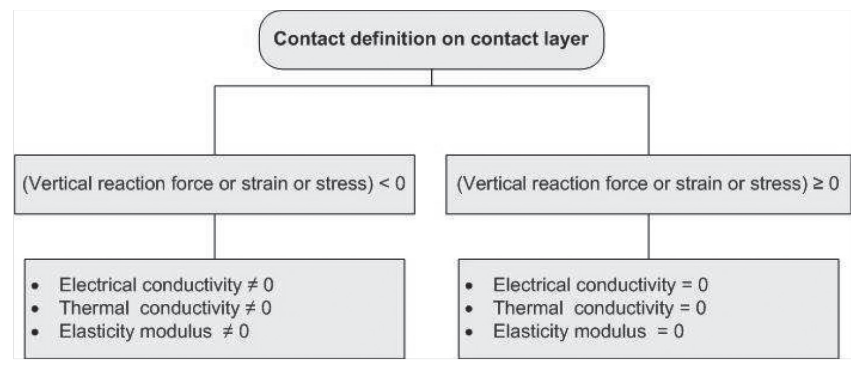

Fig. 1. The simple algorithm of contact definition method in FEA $[13,16]$ Rys. 1. Podstawowy algorytm metody definicji kontaktu w FEA $[13,16]$

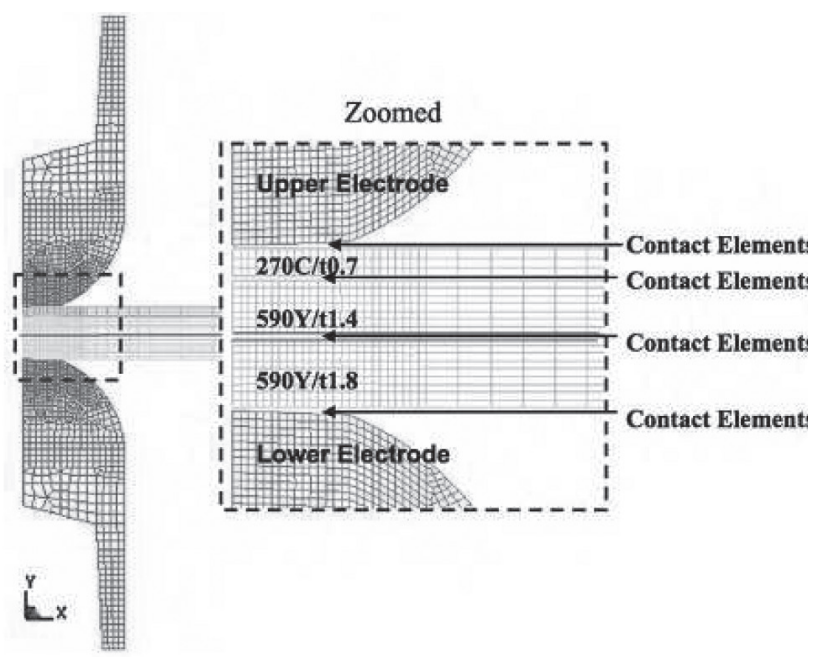

Fig. 2. Contact layers between each pair of contacting entities in RSW model [25]

Rys. 2. Warstwy stykowe pomiędzy każdą parą kontaktujących się ze sobą podmiotów w modelu RSW [25]

\section{Algorithms}

A well formed algorithm is the basis of FEA because the sequence and relationship between different aspects of the simulation process are specified in the algorithms. A general algorithm for RSW process contains initial contact definition, electrical thermal analysis, and finally, mechanical analysis. Each of these steps has some inputs as different properties needed for each analysis. A typical RSW FEA algorithm is indicated in figure 3 .

\section{Material properties}

The most important point in the application of material properties in FEA, is the considering of temperature effect on them. There are bulk and contact material properties, inside the body and over the surface of materials, respectively. Measurement of contact properties are more difficult than typical procedure used for bulk properties.

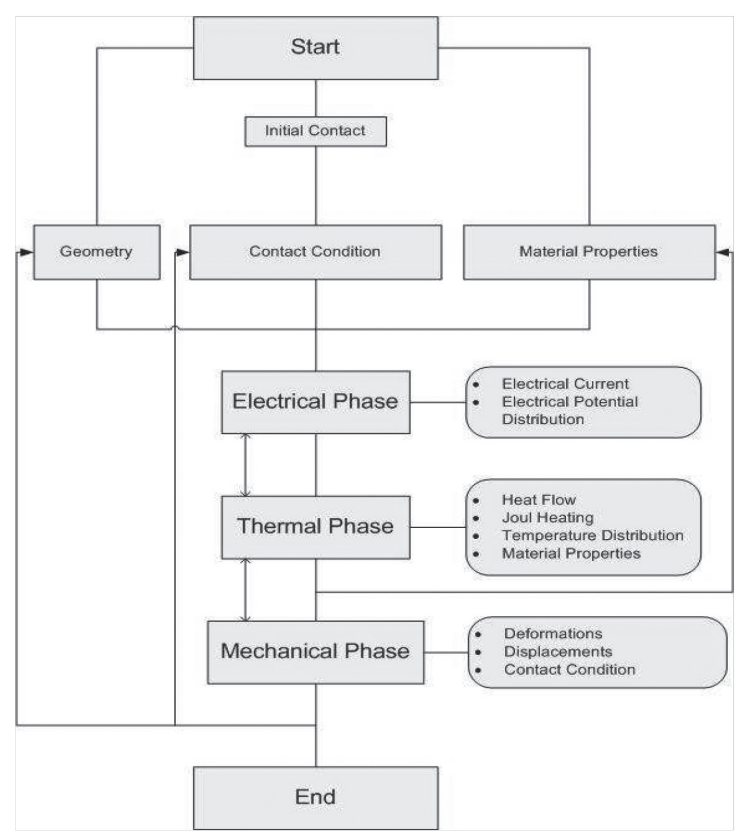

Fig. 3. A typical RSW FEA algorithm

Rys. 3. Typowy algorytm FEA RSW

\section{Bulk material properties}

For implementation of bulk properties in FEA, some of them are considered to be constant, and some as temperature dependent. Temperature independent parameters include latent heat of fusion, solidus temperature, liquidus temperatures and Poison ratio. These parameters are commonly considered to be constant all over the temperature range during RSW process. Temperature dependent parameters or variable parameters include volumetric mass density, electrical resistivity, thermal expansion coefficient, specific heat capacity, thermal conduction coefficient, elasticity modulus, and the yield strength.

\section{Contact material properties}

Contact properties are the important part of the FEA in RSW process. These properties have a significant influence on the progress of all the aspects of simulation. The most important electrical and thermal parameters are electrical contact resistivity and thermal contact conductivity, respectively. These two important temperature dependent parameters affect the heat generation rate and nugget growth in a significant manner.

Two different groups can be mentioned in definition of resistivity models, namely temperature dependent, and pressure dependent models. One of the general electrical equations used for calculation of electrical contact resistance is $[7,12]$ :

$$
\rho_{C}(T)=R_{C}\left(20^{\circ} \mathrm{C}\right) \cdot \frac{A_{C}}{L_{C}} \sqrt{\frac{\sigma_{y, \text { ave }}(T)}{\sigma_{y, \text { ave }}\left(20^{\circ} \mathrm{C}\right)}}
$$

where $p C(T)$ is an equivalent of electrical contact resistivity, $R_{C}\left(20^{\circ} \mathrm{C}\right)$ - the measured contact resistance at $20^{\circ} \mathrm{C}$ under a given force, $\sigma_{y, \text { ave }}(T)$ is the average yield strength of materials in contact, $L_{c}$ - the characteristic thickness of contact surfaces, and $A_{c}$ - the nominal contact area. Other study demonstrates a variation of the contact resistance in direct proportion to the square root of temperature [18]. 
In a pressure dependent model a constant value is supposed of the electrical contact resistivity after reaching a maximum pressure [13]. The contact resistivity is also introduced as a function of pressure between the weldments [19], or defined based on Wanhheim and Bay's friction theory of the real contact areas [23].

Instability in dynamic resistance, surface conditions, and oscillations of value of any other parameter causes these models to remain as only an estimation of the real contact resistivity. However, it is very difficult to simulate the real contact conditions to apply in FEA.

Differences in electrical and thermal properties between steel and aluminum alloys significantly change the trend of RSW process and extremes of welding parameters. Currently, the main problem in aluminum and, in general, light weight metal alloys processing, is lack of information on several electrical and thermal properties according to temperature. This gap of information needs to be filled by more experiments and measurements of bulk and contact properties of these alloys, using suitable equipments in enhanced temperatures.

\section{Precision of prediction}

The reasonable benchmark to check the accuracy of each FEM is to compare the model predicted values with experimental data. The choice of parameters to check the precision is important, because in addition to their significance, they should be measurable. Some of the most important, commonly provided as the results obtained by the model, are considered here.

\section{Diameter}

Nugget diameter is the most common parameter used in different studies to verify and check the accuracy of the predictive model. The results in Figures 4 and 5 show the increase in diameter with the rise of electrical current and with extension of welding time before expulsion phenomenon occurs.

Usually the errors observed in predicted models come from the difference in faying surface properties and from the choice of coordinates system. This issue is even more important when aluminum alloys are selected for spot welding, since in this case surface properties play a decisive role.

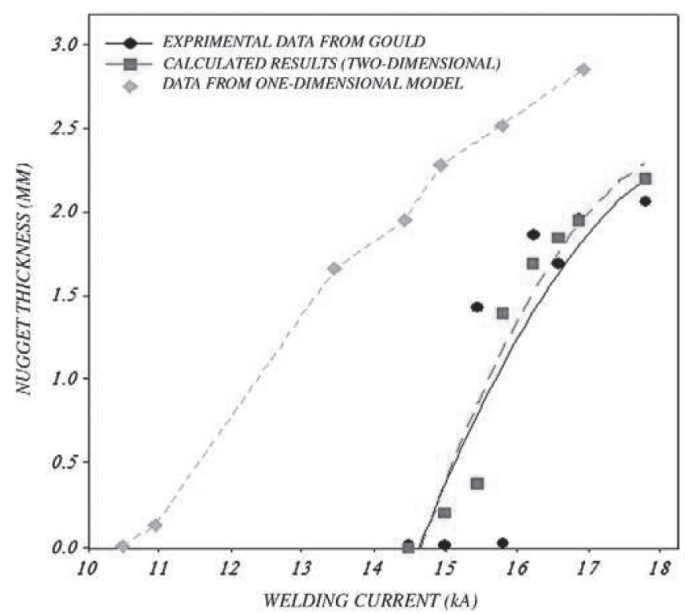

Fig. 4. Comparison of two model predicted nugget diameters with experimental results versus welding current [20]

Rys. 4. Porównanie przewidywanej przez 2 różne modele średnicy jądra zgrzeiny $z$ wynikami eksperymentu $\mathrm{w}$ funkcji wielkości prądu zgrzewania [20]

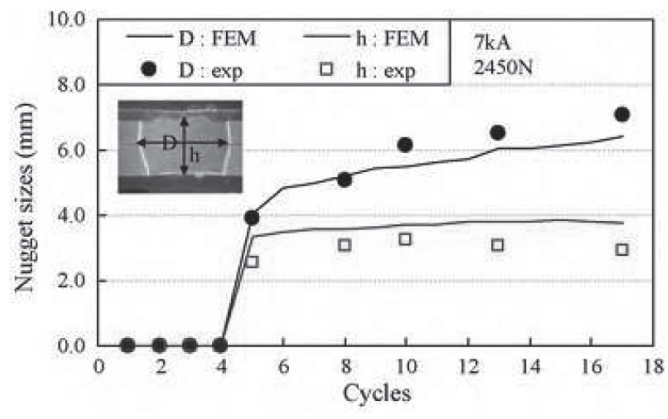

Fig. 5. Nugget growth in time [25]

Rys. 5. Wzrost jądra zgrzeiny w czasie [25]

\section{Temperature distribution}

Studies on comparison of simulated temperature distribution and experimental results are fewer than studies on nugget diameter. The main reason is related to the difficulty of temperature measurement during practical RSW.

The important features of temperature distribition diagrams which are predicted by FEMs is a delivery of information on heating and cooling rates in different locations before and after nugget melting. Figure 6 indicates the predicted rate of heating and cooling in different areas. Such results help detect existing phases in different locations and determines the possibilities of crack generation at the nugget perimeter, as in the study performed by Zhang et al. [21] who inspect the mechanical aspects of cracking during single and multi-spot welding of AA5754, experimentally and analytically. figure 8 demonstrates the predicted isothermal temperature curves, whereas figure 9 shows corresponding micrograph with cracks generated close to the welding nugget.

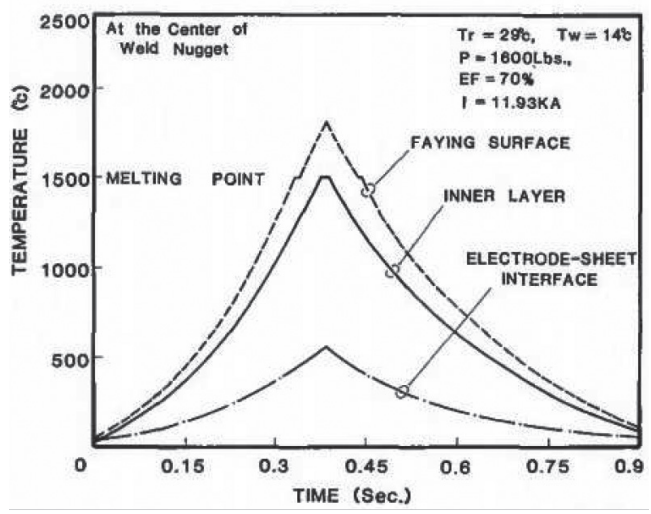

Fig. 6. Temperature in different zones of weld versus welding time [19] Rys. 6. Temperatura różnych stref zgrzeiny w funkcji czasu zgrzewania [19]

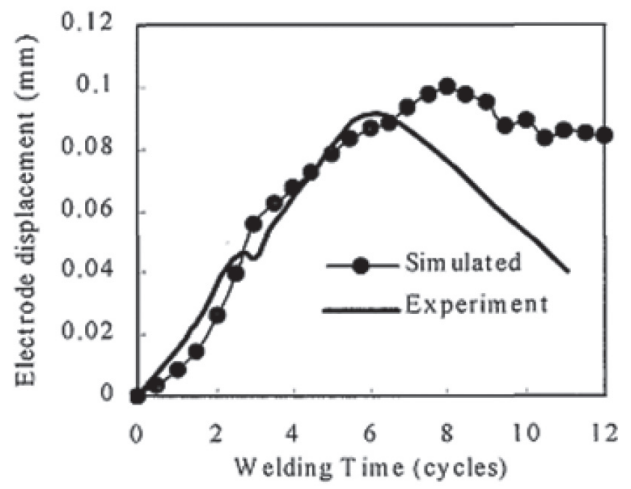

Fig. 7. Comparison of simulated and experimental electrode displacement for welding current $8.45 \mathrm{kA}$ [22]

Rys. 7. Porównanie symulowanej i otrzymanej doświadczalnie wielkości przemieszczenia elektrody dla prądu zgrzewania 8,45 kA [22] 
It is reasonably to conclude that the possibility of crack generation at the edges of nugget with densed run of predicted isotherms is higher than in other locations with mild temperature gradient. Such indirect relationship found between the cracking possibility around nuggets and predicted temperature curves is a proof for the importance of timetemperature diagrams.

\section{Electrode displacement}

Many researches conclude that displacement of electrodes could be an indicator of thermal response of the whole process. A strong proof for this statement is the similarity between electrode displacement and temperature diagrams versus welding time (Figs. 6 and 7). However, estimation of electrode displacement in RSW of aluminum alloy has different meaning comparing to that of steel, since the efficient parameter in welding aluminum alloy is surface electrical resistance while for steel it is the resistance in the bulk.

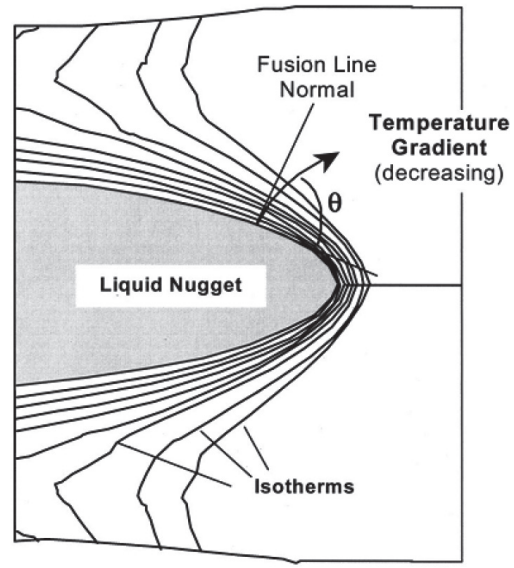

Fig. 8. Temperature distribution by a finite element analysis at the moment when heating is stopped [21]

Rys. 8. Rozkład temperatury w momencie zaprzestania grzania otrzymany metodą FEA [21]

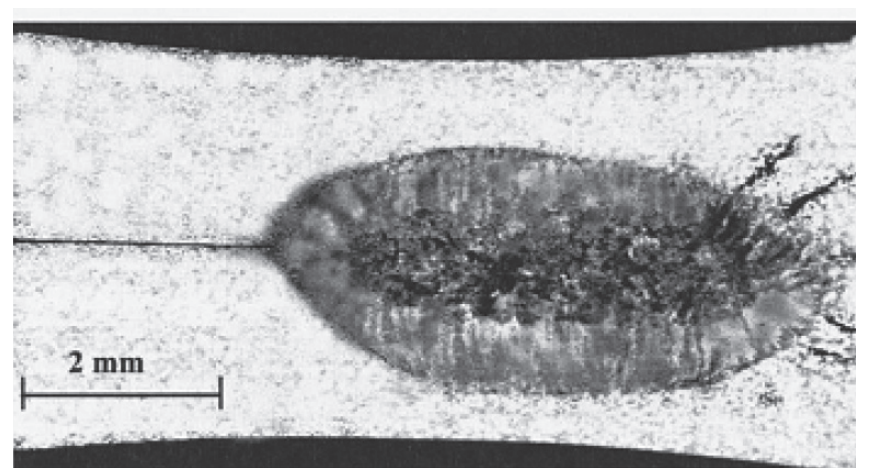

Fig. 9. Longitudinal cross-section of a single welded specimen [21] Rys. 9. Przekrój podłużny próbki z pojedynczą zgrzeiną [21]

\section{Other issues in FEA of RSW}

There are some aspects in RSW process which are not studied enough so far. These aspects are usually ignored or simplified by some assumptions in different researches. Among them are metallurgical transformations, and surface conditions.

\section{Metallurgical effects}

Micro-structural issues are not often considered in FEA of RSW, during or after the process. Most of the studies are related to find some relationship between the heating and cooling rates and final structures of spot welds, basing on existed metallurgical knowledge, especially on previously prepared phase diagrams: equilibrium ones, time-temperature-transformation (TTT) or continuous-cooling-transformation (CCT) diagrams. Among others, the model developed by Babu et al. [26] is noticeable. The concept of this study basis on the relationship between the temperature profile obtained by FEM for different nodes in the fusion zone (FZ) and heat affected zone (HAZ), and TTT diagrams for specific type of steel.

Researches in the field need deeper knowledge on metallurgical changes to introduce into the models dedicated to different group of alloys. Since the ideal model should be able to predict the final FZ and HAZ structure after given RSW process, such a task requires a huge effort by authors to complete and implement all existed informations and materials data inside the developed model.

\section{Surface conditions}

There are a few studies on modeling the behavior of surface conditions. The importance of them and importance of contact properties are prevailed for light weight metals as aluminum or magnesium but they play also main influential role in RSW of steels and any other alloys [8]. The requirement to model the behavior of surface conditions including the presence of oxide layers and its roughness needs a precise definition of geometry and mechanical properties of whole surface factors to consider the role of this layer at the initial and subsequent stages of the analysis.

\section{Important case studies in FEA of RSW}

There are several studies in the field of ordinary single RSW process with similar approaches. The work on such models could be beneficial since new configurations in contemporary industry become common. Therefore, most of models suitable for special case studies are designed to match the intended industrial or scientific purposes. Here some of the specific models are descriebed.

\section{FEA of RSW with cover plates}

Shi et al. [24] performed a study in which RSW process of magnesium alloy sheets went on between the covering plates (fig. 10). As it is shown in fig. 11, the weld was unable to attain by conventional RSW without the use of cover plates when welding current is below $9 \mathrm{kA}$. Additional heat generated in cover plates of low electrical conductivity transferred to the welding region, which resulted in the formation of large nugget. Therefore, RSW with cover plates can improve the performance of magnesium alloy weld. The analysis and simulation in such configuration is more complicated due to additional contacting surfaces of covering plates with electrodes and with sheets to be welded.

\section{FEA of shunting effect in RSW}

Considering shunting effect in addition to the other complexities of the analysed process adds more assumptions to the simulation procedure. First objective in analysis of shunting effect is the obtaining of voltage distribution. Due to the existence of shunting current, there is not symmetry in the configuration, therefore the axisymmetric equations are of no use and the general three-dimensional equations must be used instead. This adds to the complexity and calculation time. Furthermore, the temperature changes 


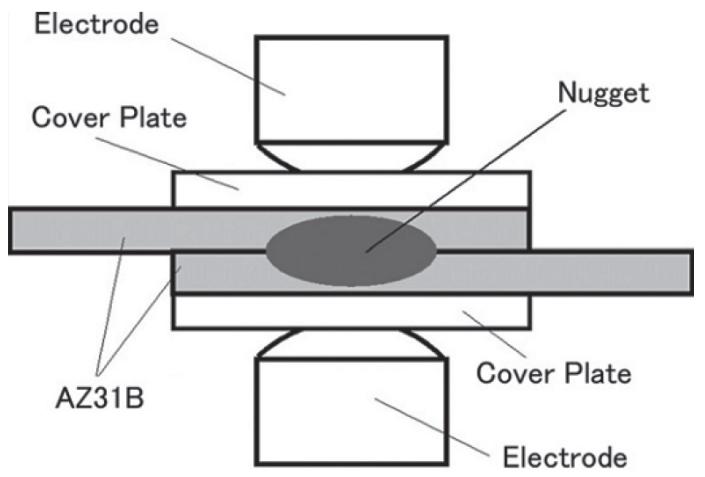

Fig. 10. Schematic diagram of spot welding with cover plats [24] Rys. 10. Schemat zgrzewania punktowego z nakładkami [24]

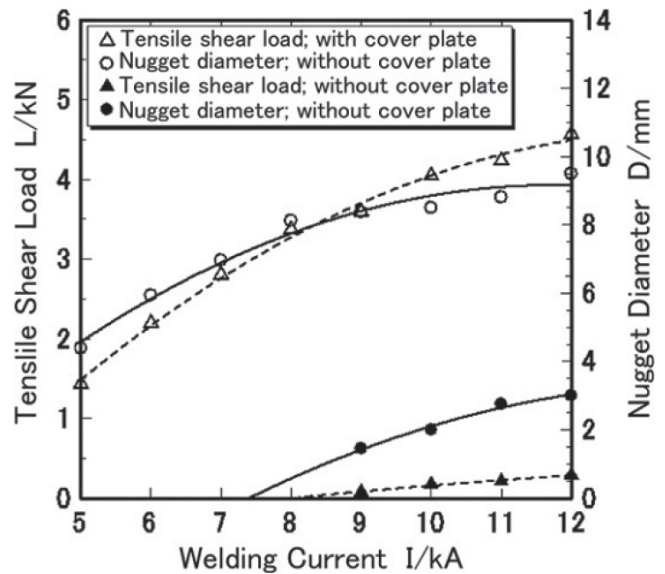

Fig. 11. Effects of welding current on tensile shear load and nugget diameter [24]

Rys. 11. Wpływ prądu zgrzewania na wytrzymałość zgrzeiny na ścinanie i na średnicę jej jądra [24]

occur during the whole process should be taken into account for each iteration which increases again the calculation time and effort.

FEA studies on shunting effect are fewer than the experimental ones [11]. A finite element electro-thermal analysis was performed by Chang [10] with an experimental test added for verification of the model. Figure 12 (a) and (b) indicate the results of electrical potential (or current) and temperature distribution, respectively. The results are compatible with experimental results as the asymmetry is obvious in the distribution of voltage and temperature.

\section{FEA of multiple sheet RSW}

Shen et al. [17] developed a thermal-mechanical and electrical-thermal model to predict the nugget formation process in welding three sheets of steel. Figure 13 shows the geometry and boundary conditions used in this study. In figure14 a comparison is indicated between calculated and experimental results for a given electrical current and electrode force after 14 cycles of welding time. According to the authors, the reason of nugget size underestimation in the model is the difference between real and assumed electrical resistance of the top and middle sheet.

\section{FEA of single-sided RSW}

Kim et al. [23] considered all of the mechanical, thermal, electrical, and also metallurgical aspects in their model of single-sided RSW. The single-sided electrode model generates a current path between an electrode and the ground that is far distant from the electrode and varies according to the shape of the weldment (Fig. 15).
Although this method is a convenient approach for the situation where there is not enough access to the other side of the weldments, main problem is the lack of electrode force on the opposite side. Reduction of localized electrode force may cause less deviation of the sheet and avoid the electrode mark over the sheet surface but altering the field of squeezing stresses might lead to expulsion or a weld formation of unsufficient size.

a)

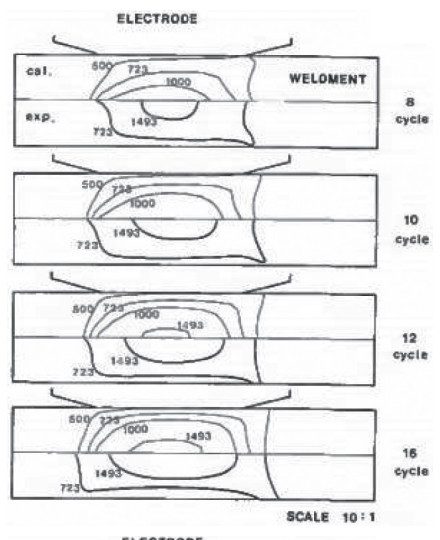

b)

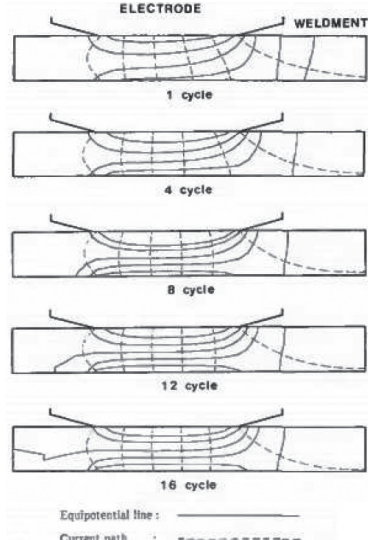

Fig. 12. Results of FEM modeling for the shunted weld [10]: (a) variation in distribution of temperature (b) distribution of electrical voltage and current

Rys. 12. Wyniki obliczeń FEM dla zgrzeiny bocznikowanej [10]: (a) zmiana rozkładu temperatury w czasie zgrzewania (b) rozkłady napięcia i prądu

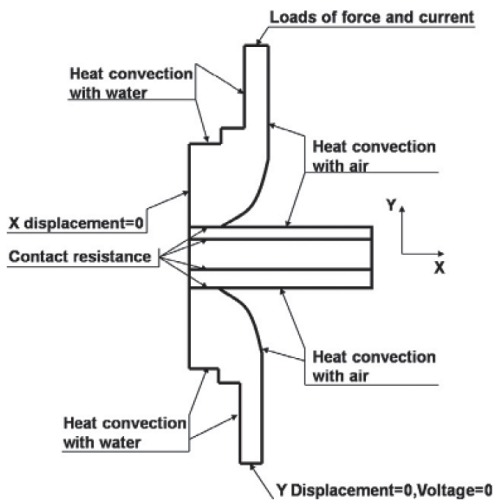

Fig. 13. Scheme and boundary conditions of the model used for three sheets RSW [17]

Rys. 13. Schemat i warunki brzegowe dla modelu zastosowanego do RSW trzech blach [17]

\section{Suggestions}

Fully coupled analysis of RSW process is not often seen among the researches. Most of the studies used thetraditional decoupled electrical-thermal or mechanical-thermal approach. Electrical, thermal, and mechanical interactions could 
be visualized more in a fully coupled model than separated models, however calculation time and effort rises in this case. A few studies on modeling of surface conditions were done, however there is lack of models considering the effect of oxide layer and its mechanical destruction by the electrode during squeezing and welding stages of RSW.

The effect of shunting electrical current is not adequately investigated in previous studies. Most of researches deal with a subsidiary description of shunting current when other elec-

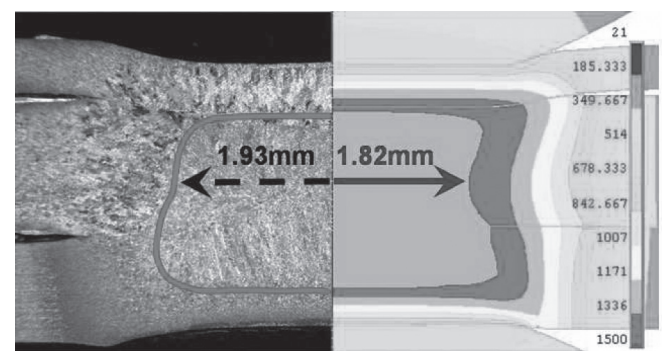

Fig. 14. Comparison of calculated and experimental nugget diameter for 14th cycle [17]

Rys. 14. Porównanie obliczonej i otrzymanej doświadczalnie wielkości jądra zgrzeiny po 14 cyklach prądu zgrzewania [17] trical conductive routes exist next to the main welding spot. The structure, conductivity, cross-section area, distance to the spot, and number of these shunting routes are the important aspects which require more investigations in FEA of RSW.

The unique nature of alloys makes it difficult the prediction of resulting microstructure of weldments. Further efforts are desirable in this field to establish a stronger link between thermal and mechanical processes, and final structure of the welding nugget and HAZ by FEM.

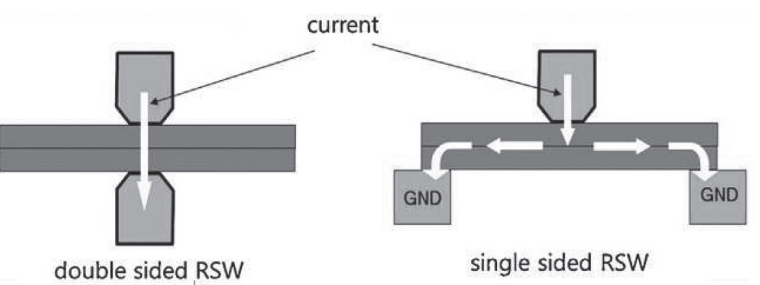

Fig. 15. Electrical current path in the single- and the double-sided electrode RSW [23]

Rys. 15. Droga przepływu prądu elektrycznego podczas zgrzewania punktowego jedno-i dwustronnego [23]

\section{Conclusions}

1. Advantages of FEM versus FDM made the first more common in FEA software and therefore recent studies usually use the method as more flexible to any geometry.

2. The main differences in FEA applied models rely on various definitions of electrical and thermal contact properties with miscellaneous approaches to their dependence on temperature and pressure.

3. Most effective materials property in RSW models is the electrical contact resistance which controls the amount of heat generated and influences the whole analysis procedure.

4. Modeling in new configurations is appreciated in terms of widening the borders of RSW knowledge, although more reworking and verifications are required to improve the reliability of FEA results.

\section{References}

[1] Archer, G. (1960), „Calculations for Temperature Response in Spot Welds”. Welding Journal, 39, 327s-330s.

[2] Greenwood, J.A. (1961), „Temperature in spot welding”, British Welding Journal 8 (6), 316-322.

[3] Gould, J. E. (1987), „An examination of nugget development during spot welding, using both experimental and analytical techniques", Welding Journal, 66 (1), $1 \mathrm{~s}-10 \mathrm{~s}$.

[4] Nied , A. (1984), "The finite element modeling of resistance spot welding process", Welding Journal 63 (4), 123-132.

[5] Huh , H., Kang, W.J. (1997), „Electro-thermal analysis of electrode resistance spot welding process by a 3-D finite element method", Journal of Materials Processing Technology 63, 672-677.

[6] Loulou, T., Masson, P., Rogeon, P. (2006), “Thermal characterization of resistance spot welding", Numerical Heat Transfer Part B: Fundamentals 49 (6), 559-584.

[7] Tsai, C.L., Jammal, O.A., Papritan, J.C., Dickinson, D.W. (1992), „Analysis and development of a real time control methodology in resistance spot welding", Welding Journal 70 (12), 339s-351s.

[8] Zhang, H., Senkara, J. (2011), „Resistance Welding: Fundamentals and Applications - 2nd Edition”, Chapters 1-7, CRC Press, UK

[9] Hard, A. R. 1948. „Preliminary test of spot weld shunting in 24ST Alclad”, Welding Journal 27(6): 491-495.

[10] Chang, H. S., Cho, H. S. (1990), "A Study on the Shunt Effect in Resistance Spot Welding", Welding Journal 69 (8), 308-316.

[11] Wang, B., Lou, M., Shen, Q., Li, Y. B., Zhang, H. (2013), „Shunting effect in resistance spot welding steels - part 1: experimental study", Welding Journal $92(6), 182 \mathrm{~s}-189 \mathrm{~s}$

[12] Hamedi, M., Eisazadeh, H., Esmailzadeh, M. (2010), „Numerical simulation of tensile strength of upset welded joints with experimental verification", Material \& Design 31, 2296-2304.

[13] Sun, X., Dong, P. (2000), "Analysis of Aluminum Resistance Spot Welding Processes Using Coupled Finite Element Procedures", Welding Journal, 79 (8), 215-s-221-s

[14] Yamamoto, T., Okuda, T., 1971, „A study of spot welding of heavy gauge mild steel" Welding in the World $9(7-8), 234-255$
[15] Hou, Z., Kim, I., Wang, Y., Li, C., Chen, C. (2007), „Finite element analysis for the mechanical features of resistance spot welding process", Journal of Materials Processing Technology 185, 160-165.

[16] Murakawa, H., Zhang, J. (1998), „FEM simulation of spot welding process: effect of initial gap on nugget formation", Transactions of JWRI 27 (1), $75-82$

[17] Shen, J., Zhang, Y., Lai, X., Wang, P.C. (2011), “Modeling of resistance spot weIding of multiple stacks of steel sheets", Materials and Design 32, 550-560.

[18] Cho, H.S., Cho, Y.J. (1989), „A study of the thermal behavior in resistance spot welding", Welding Journal 68 (6), 236s-244s.

[19] Han, Z., Orozco, J., Indacochea, E., Chen, C.H. (1989), „Resistance spot weIding: a heat transfer study", Welding Journal 68 (9), 363s-371s.

[20] Eisazadeh, H., Hamedi, M., Halvaee, A. (2010), "New parametric study of nugget size in resistance spot welding process using finite element method", Materials and Design 31 (1), 149-157.

[21] Zhang, H., Senkara, J., Wu, X., (2002), "Suppressing cracking in resistance welding AA5754 by mechanical means", Transactions of ASME - Journal of Manufacturing Science and Engineering, 124, 79-85.

[22] Murakawa, H., Zhang, J., Fujii, K., Wang, J., Ryudo, M. (2000), „FEM simulation of spot welding process: characteristics of electrode displacement and nugget formation", Transactions of JWRI 29 (1), 73-80.

[23] Kim, J.H., Cho, Y., Jang, Y.H. (2013), "Estimation of the weldability of single-sided resistance spot welding", Journal of Manufacturing Systems 32, 505-512.

[24] Shi, H., Qiu, R., Zhu, J., Zhang, K., Yu, H., Ding, G. (2010), „Effects of weIding parameters on the characteristics of magnesium alloy joint weIded by resistance spot welding with cover plates", Materials and Design 31, 4853-4857.

[25] Ma, N., Murakawa, H. (2010), „Numerical and experimental study on nugget formation in resistance spot welding for three pieces of high strength steel sheets", Journal of Materials Processing Technology 210, 2045-2052.

[26] Feng, Z., Babu, S.S., Santella, M.L., Riemer, B.W., Gould, J.E. (1998) „An incrementally coupled electrical-thermal-mechanical model for RSW", in Proc. of 5th Int. Conf. on Trends in Welding Research, ASM Int., Pine Mountain, 599. Also: Babu, S.S., Web site: http://mjndeweb.ms.orln.gov?Babu/default.html 